\title{
Resurrection of Hyalinobatrachium orocostale and Notes on the Hyalinobatrachium orientale Species Complex (Anura: Centrolenidae)
}

Author(s) :Santiago Castroviejo-Fisher, J. Celsa Señaris, José Ayarzagüena, and Carles Vilà

Source: Herpetologica, 64(4):472-484. 2008.

Published By: The Herpetologists' League

DOI:

URL: http://www.bioone.org/doi/full/10.1655/07-049R2.1

BioOne (www.bioone.org) is a a nonprofit, online aggregation of core research in the biological, ecological, and environmental sciences. BioOne provides a sustainable online platform for over 170 journals and books published by nonprofit societies, associations, museums, institutions, and presses.

Your use of this PDF, the BioOne Web site, and all posted and associated content indicates your acceptance of BioOne's Terms of Use, available at www.bioone.org/page/ terms of use.

Usage of BioOne content is strictly limited to personal, educational, and non-commercial use. Commercial inquiries or rights and permissions requests should be directed to the individual publisher as copyright holder. 
Herpetologica, 64(4), 2008, 472-484

(C) 2008 by The Herpetologists' League, Inc.

\title{
RESURRECTION OF HYALINOBATRACHIUM OROCOSTALE AND NOTES ON THE HYALINOBATRACHIUM ORIENTALE SPECIES COMPLEX (ANURA: CENTROLENIDAE)
}

\author{
Santiago Castroviejo-Fisher ${ }^{1,5}$, J. Celsa Señaris ${ }^{2}$, José Ayarzagüena ${ }^{2,3}$, and Carles Vilì $\AA^{1,4}$ \\ ${ }^{1}$ Department of Evolutionary Biology, Evolutionary Biology Centre (EBC), Uppsala University, Norbyvägen 18D, \\ 75236 Uppsala, Sweden \\ ${ }^{2}$ Museo de Historia Natural, Fundación La Salle de Ciencias Naturales, Apartado 1930, Caracas 1010-A, Venezuela \\ ${ }^{3}$ Asociación Amigos de Doñana, Panama 6, 41012 Sevilla, Spain \\ ${ }^{4}$ Estación Biológica de Doñana-CSIC, Avd. María Luisa s/n, 41013 Sevilla, Spain
}

\begin{abstract}
AвstRact: Hyalinobatrachium orientale has a complex taxonomic history suggesting that more than one species could be under this name. In this review, we try to clarify the current taxonomic status of this species by means of morphological, bioacoustic, and mitochondrial DNA sequence comparisons of specimens from Tobago Island and the Venezuelan Cordillera de la Costa (Oriental Sector, Cordillera del Litoral and Cordillera del Interior). Our data support the resurrection of Hyalinobatrachium orocostale, restricted to the Cordillera del Interior. Additionally, specimens from Cordillera del Litoral and Oriental Sector do not form a monophyletic group; hence, we define as Hyalinobatrachium sp. the populations from Cordillera del Litoral and $H$. orientale sensu stricto the populations from the Oriental Sector. Preliminary bioacoustic and morphological analyses indicate that the populations from Tobago are conspecific with Hyalinobatrachium orientale sensu stricto.
\end{abstract}

Key words: Cordillera de la Costa; Cryptic species; Glassfrogs; Mitochondrial DNA; Taxonomy; Tobago; Venezuela

Frogs of the subfamily Centroleninae (Frost et al., 2006), also known as glassfrogs, constitute a monophyletic group (e.g., Darst and Cannatella, 2004; Frost et al., 2006; Guayasamin et al., 2008; Ruiz-Carranza and Lynch, 1991; Wiens et al., 2005) that currently contains 147 species (AmphibiaWeb, 2006) distributed throughout the Neotropical wet forests. Glassfrogs are currently classified in four genera: Centrolene, Cochranella, Hyalinobatrachium and Nymphargus (CisnerosHeredia and McDiarmid, 2007; Ruiz-Carranza and Lynch, 1991), and although its alpha diversity has experienced an increase during recent years (Frost, 2007), several taxonomic problems remain unresolved (e.g., Cisneros-Heredia and McDiarmid, 2007; Guayasamin et al., 2008; Kok and Castroviejo-Fisher, 2008; Kubicki, 2007).

In this work we re-evaluate the taxonomic status of Hyalinobatrachium orientale (Rivero, 1968). This species has a complicated history, and several authors suspect that it is a complex of various cryptic species (Myers and Donnelly, 1997; Señaris and Ayarzagüena, 2005).

\footnotetext{
${ }^{5}$ Correspondence: e-mail, santiago.castroviejo@ebc. uu.se
}

As things stand, $H$. orientale is distributed throughout the central eastern ranges of the Cordillera de la Costa (coastal mountain range) in Venezuela and several localities in Tobago Island with an altitudinal range of 190-1200 m (Señaris and Ayarzagüena, 2005). Prior to the description of $H$. orientale, specimens of this species were mainly assigned to Centrolenella fleischmanni (Goin, 1964) or C. cappellei (S. Castroviejo-Fisher, personal observation of museum materials, MBUCV 3018), now in the synonymy of $H$. fleischmanni after Goin (1964). Later, Rivero (1968) described C. orientalis (from Cerro Turimiquire, Oriental Sector, Fig. 1, in the border of Sucre and Monagas, Venezuela) and C. orocostalis (from Cerro Platillón, Cordillera del Interior, Central Sector, Guárico, Venezuela) based on comparisons of just one specimen of $C$. orientalis (the holotype) and eight of $C$. orocostalis (type series). The two species were differentiated by head shape, tympanum visibility, white tunic around the eye and size of melanophores. Hardy (1982) tentatively identified a Centrolenella from Tobago as orientalis. Later, he (Hardy, 1984) described the Tobago specimens as C. $o$. tobagoensis. Cannatella and Lamar (1986) 
reviewed the taxonomic status of $C$. orientalis, C. o. tobagoensis and C. orocostalis and concluded that they constituted a single species (C. orientalis) distributed from Colombia to the Venezuelan Guayana and Tobago through the Cordillera de la Costa and that the variation among specimens did not represent separate taxonomic entities but just interpopulation variability. Ruiz-Carranza and Lynch (1991) placed C. orientalis in the genus Hyalinobatrachium, and Murphy (1997) continued to recognize the subspecies tobagoense ( $=$ tobagoensis). Ruiz-Carranza and Lynch (1998) thought that the material from Colombia that Cannatella and Lamar (1986) assigned to $H$. orientale was wrongly identified but, to our knowledge, did not provide a new identification.

Señaris and Ayarzagüena (2005) reviewed the taxonomy of Venezuelan glassfrogs and identified as Hyalinobatrachium crurifasciatum Myers and Donnelly the specimens from La Escalera (Bolívar, Venezuela) that Cannatella and Lamar (1986) cited as H. orientale. In spite of noticing some differences between populations (coloration in life and vocalizations), they also considered $H$. orocostale (= orocostalis) as a junior synonym of $H$. orientale because they considered that the available data did not support specific differentiation between the populations (Señaris and Ayarzagüena 2005:217). However, Señaris and Ayarzagüena (2005) excluded from the species's distribution the localities from the Cordillera del Litoral (Central Sector, Aragua, Venezuela) cited by Cannatella and Lamar (1986), where one of the paratypes of $H$. orocostale was found. Señaris and Ayarzaguiena (2005) suggested that the specimens from the northern versant of the Cordillera de la Costa assigned to $H$. orientale by Cannatella and Lamar (1986) were most likely $H$. fragile Rivero; however, Señaris and Ayarzagüena (2005) refrained from proposing any taxonomic change because specimens were not examined.

Here we test the hypothesis that Hyalinobatrachium orocostale is a different species from $H$. orientale by means of an integrative taxonomy approach (Will et al., 2005). We use morphology, molecular phylogenetics, and bioacoustics to study species boundaries, provide new data on the advertisement call of the populations from Tobago, and comment on the cryptic diversity of $H$. orientale.

\section{Materials and Methods \\ Nomenclature and Terminology}

We used the supra-generic classification of Frost et al. (2006). We are aware that this classification may be changed in the future (Guayasamin and Trueb, 2007), but we chose to follow it until a detailed systematic study of the family is conducted. We followed Ruiz-Carranza and Lynch (1991, 1998) for the generic and infra-generic classification. However, following Cisneros-Heredia and McDiarmid (2007) we do not recognize the species subgroup chirripoi.

Following Huber (1997) and Rivero (1964), we divided the Venezuelan Cordillera de la Costa in two sectors: Central and Oriental (see Fig. 1). The Central Sector is divided into Cordillera del Litoral along the coast, and Cordillera del Interior, which runs parallel to the Cordillera del Litoral but inland. The Oriental Sector extends from the Unare depression to the western tip of the Paria Peninsula.

\section{Morphology}

Museum voucher specimens were preserved in $70 \%$ ethanol, and some of them were fixed in $4-10 \%$ formalin. For the description of morphological and color characteristics we follow Cisneros-Heredia and McDiarmid (2007), Flores (1985), Lynch and Duellman (1973), and Señaris and Ayarzagüena (2005). Diagnostic characters were arranged according to Cisneros-Heredia and McDiarmid (2007). Terminology for webbing follows Savage and Heyer (1967) as modified by Guayasamin et al. (2006). Institution abbreviations are those of Frost (2007), but with the addition of MCNC, Museo Ciencias Naturales Caracas, Venezuela. Specimens examined are listed in the Appendix.

With a digital caliper we measured, to the nearest $0.01 \mathrm{~mm}$, snout-vent length (SVL), head length (from rictus to tip of snout), head width (at level of rictus), shortest interorbital distance, eye diameter (horizontal), distance from anterior margin of eye to snout tip, width 


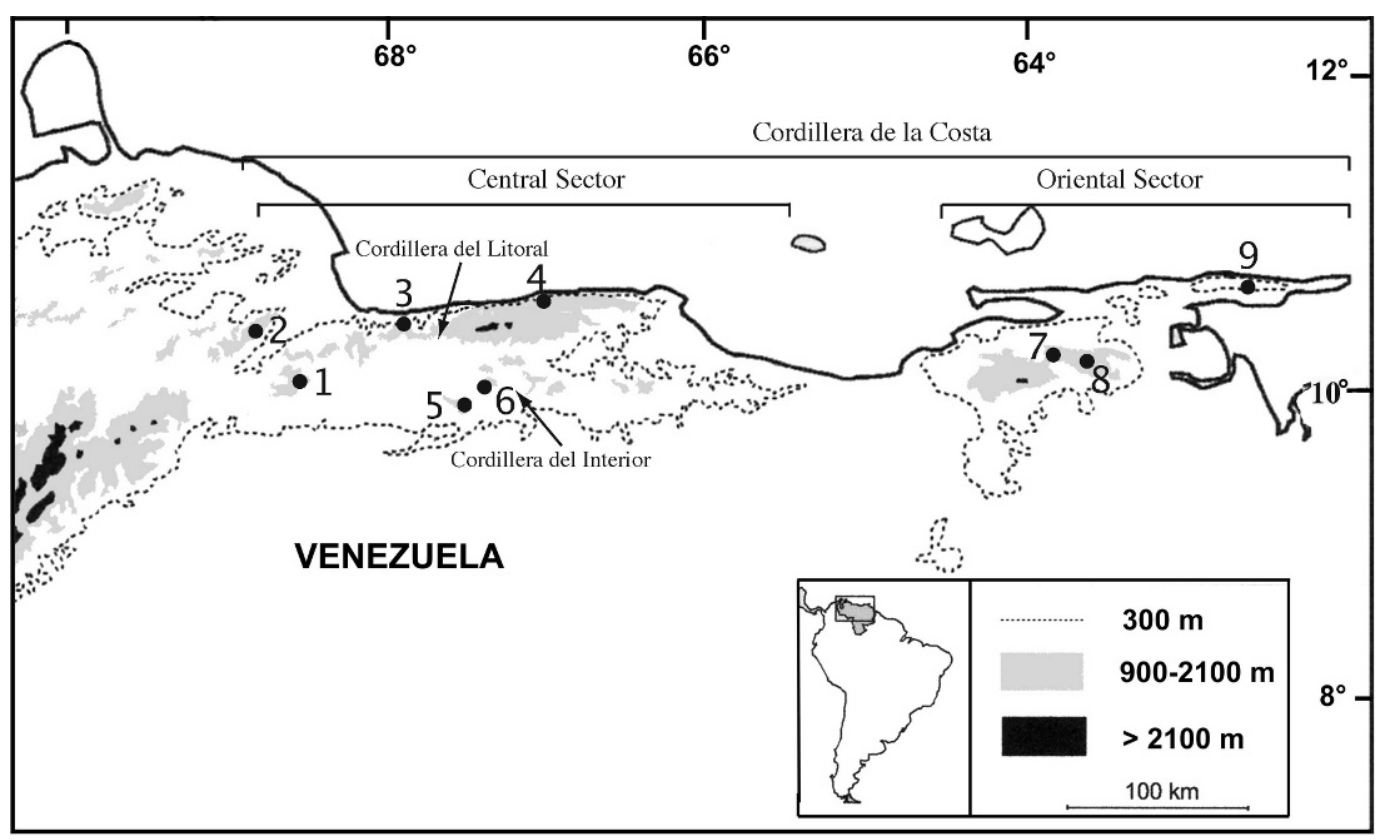

FIG. 1. Distribution of Hyalinobatrachium fragile $(1,2,3,4)$, H. orientale $(7,8,9)$, H. orocostale $(5,6)$, and $H$. sp. (3) in Venezuela. 1 = La Sierra, Cojedes; 2 = Sierra de Aroa, Yaracuy; 3 = Rancho Grande, Aragua; 4 = Hacienda El Limón, Distrito Federal; $5=$ Monte Platillón, Guárico; $6=$ Hacienda La Canopia, Aragua; 7 = Cerro Turimiquire, SucreMonagas; 8 = Cueva del Guácharo, Monagas; 9 = Península de Paria, Sucre.

of the terminal disk of the third finger, femur length (distance from the middle of the cloacal slit to the femur-tibia articulation), tibia length (from the femur-tibia articulation to the tibia-heel articulation). Throughout the text, the observed range for each measurement for each species is followed by mean \pm standard deviation.

Color characteristics were noted from live individuals, photograph collections, descriptions, and photographs in the literature (Cannatella and Lamar, 1986; Rivero, 1968; Señaris and Ayarzagüena, 2005).

\section{Bioacoustics}

We recorded frog vocalizations in the field with a Sony WM D6C tape recorder and a Sennheiser Me 80 directional microphone. The sounds were digitized and edited at a sampling frequency of $44.1 \mathrm{KHz}$ and 16 bit resolution with a Delta 66 digitalizing board and Peak 3.2 software in an Apple Macintosh computer. We also analyzed the recordings of the advertisement calls of Hyalinobatrachium orientale tobagoense included in Read (2001). All calls were edited with Audacity 1.2.6 for MacOS X
(Mazzoni and Dannenberg, 1999). The software Praat 4.5.02 for MacOS X (Boersma and Weenink, 2006) was used to obtain numerical information and to generate audiospectrograms and oscillograms. Frequency information was obtained through Fast Fourier Transformations (FFT) (width, 1024 points).

\section{Genetic Analyses}

We considered two different criteria to delineate species boundaries using DNA data: monophyly and genetic distances (de Queiroz 1998). The first of these approaches assumes that evolutionarily independent lineages (species sensu Simpson, 1961, and Wiley, 1978) normally become reciprocally monophyletic after a long time in isolation. The second assumes that genetic variation within a species tends to be small and does not overlap variation among species.

We genetically analyzed six specimens of Hyalinobatrachium orientale from different localities (see Appendix): three from the Oriental Sector, two from the Cordillera del Interior and one from the Cordillera del Litoral. We also include two sequences of $H$. 
fragile, the only species in the Cordillera de la Costa that also has a transparent pericardium. Monophyly of the $H$. fleischmanni Group, which includes these species, has been supported by Guayasamin et al. (2006), Guayasamin et al. (2008), Ruiz-Carranza and Lynch (1991; 1998) and citations therein. We used H. anthistenesi Goin to root the phylogenetic trees.

Genomic DNA was extracted from Lairds buffer or ethanol-preserved tissues using a standard phenol-chloroform extraction protocol (Sambrook et al., 1989). A fragment of approximately $850 \mathrm{bp}$ of the mitochondrial ribosomal gene $16 \mathrm{~S}$ was amplified and sequenced using previously described primers (16SC-5' and 16Sbr-3') and PCR conditions (Hillis et al., 1996). This fragment performs better than COI for amphibian species identification through DNA barcodes (Vences et al., $2005 a, b)$ and has been broadly used in amphibian phylogenies (e.g., Darst and Cannatella, 2004; Frost et al., 2006). PCR products were visualized in agarose gels and sequenced in an ABI 3730xl Genetic Analyzer (Applied Biosciences). Sequences from heavy and light strands were compared to generate a consensus sequence for each specimen using Sequencher 4.1 (Gene Codes Corp., 2000). Three sequences (EU447289-91) were graciously provided by J. M. Guayasamin and J. ValeraLeal. Sequences were aligned in CLUSTAL_X (Thompson et al., 1997) using default parameters. To allow repeatability and to avoid introducing subjective hypotheses of homology, sequences were not aligned by hand. We used PAUP* 4.0bl0 (Swofford, 2002) to calculate uncorrected pair-wise distances (p). The same program was used to construct a neighbor joining phylogenetic tree (using uncorrected $\mathrm{p}$ distance) and for an exhaustive search of the most parsimonious tree. The support of the internal nodes in the trees was assessed using 5000 and 1000 nonparametric bootstrap pseudoreplicates for the neighbor joining and parsimony analyses, respectively.

\section{REsults \\ Morphology}

Specimens from the Oriental Sector and the Cordillera del Interior had very similar external morphological characters and morphometric ratios (we did not have access to material from Tobago and Cordillera del Litoral). However, two qualitative characters allowed their separation (characters of specimens from the Oriental Sector in parentheses): (i) presence of glands on the lateral fringes of fingers-except internal fringe of Finger III—and on the membranes between the fringes in males (absent); (ii) absence of big melanophores (present in $50 \%$ of specimens examined). However, we refrain to use them as unambiguous characters because these glands could be dependent on sexual activity and/or preservation state of the specimens, and dorsal coloration variability of specimens from the Oriental Sector encompassed that of those from the Cordillera del Interior.

The morphometric comparison of the two populations (Table 1) showed that the range of the ratio values overlapped to some degree in all but one proportion: eye diameter/head length. However, in spite of our small sample size (particularly for specimens from the Cordillera del Interior) an unequal variance $t$-test indicated differences between males from the different populations in head length/SVL (sample sizes indicated as subindexes: $t_{10}, 3=3.145, P=0.023$ ), eye diameter/head length $\left(t_{10,3}=-3.973, P=\right.$ 0.002), and disc of Finger III/eye diameter $\left(t_{10,3}=3.040, P=0.020\right)$. Furthermore, a principal component analysis of morphological proportions in males discriminated specimens from the Cordillera del Interior from those of $H$. orientale (Oriental Sector) and $H$. fragile (Fig. 2). The first two components explained $63.7 \%$ of the variance. Component 1 was most influenced by head proportions (head width/head length and head length/ SVL), while Component 2 by proportions of some head elements (eye diameter/head length and eye-to-snout/interorbital distance) (Table 2).

\section{Bioacoustics}

The calls recorded at Cerro Platillón in the Cordillera del Interior ( $n=9$, one specimen) were clearly different from those of the Oriental Sector ( $n=15$, five specimens) and Tobago $(n=13$, two specimens) (Table 3, 
TABLE 1.-Range of body proportions of Hyalinobatrachium fragile; H. orientale, and H. orocostale (in parenthesis, mean \pm standard deviation).

\begin{tabular}{|c|c|c|c|c|c|c|}
\hline Species and Distribution & H. fragile Cordil & ra del Litoral & H. orientale Orien & al Sector & H. orocostale Cordille & del Interior \\
\hline Sex & $\begin{array}{l}\text { Males } \\
(n=16)\end{array}$ & $\begin{array}{l}\text { Females } \\
\quad(n=5)\end{array}$ & $\begin{array}{l}\text { Males } \\
(n=10)\end{array}$ & $\begin{array}{l}\text { Females } \\
\quad(n=1)\end{array}$ & $\begin{array}{l}\text { Males } \\
(n=3)\end{array}$ & $\begin{array}{l}\text { Females } \\
\qquad(n=1)\end{array}$ \\
\hline Head width/Head length & $\begin{array}{l}1.17-1.34 \\
(1.25 \pm 0.06)\end{array}$ & $\begin{array}{l}1.15-1.35 \\
(1.25 \pm 0.07)\end{array}$ & $\begin{array}{l}1.18-1.35 \\
(1.23 \pm 0.05)\end{array}$ & 1.35 & $\begin{array}{l}1.08-1.22 \\
(1.15 \pm 0.07)\end{array}$ & 1.17 \\
\hline Head length/SVL ${ }^{1,2}$ & $\begin{array}{l}0.27-0.33 \\
(0.29 \pm 0.01)\end{array}$ & $\begin{array}{l}0.26-0.32 \\
(0.29 \pm 0.02)\end{array}$ & $\begin{array}{l}0.29-0.33 \\
(0.30 \pm 0.01)\end{array}$ & 0.29 & $\begin{array}{l}0.32-0.34 \\
(0.33 \pm 0.01)\end{array}$ & 0.32 \\
\hline Head width/SVL & $\begin{array}{l}0.34-0.40 \\
(0.36 \pm 0.01)\end{array}$ & $\begin{array}{l}0.34-0.39 \\
(0.37 \pm 0.02)\end{array}$ & $\begin{array}{l}0.36-0.39 \\
(0.37 \pm 0.01)\end{array}$ & 0.39 & $\begin{array}{l}0.37-0.40 \\
(0.38 \pm 0.01)\end{array}$ & 0.37 \\
\hline $\begin{array}{l}\text { Eye diameter/Head } \\
\text { length }^{1,2}\end{array}$ & $\begin{array}{l}0.39-0.54 \\
(0.45 \pm 0.04)\end{array}$ & $\begin{array}{l}0.45-0.49 \\
(0.47 \pm 0.02)\end{array}$ & $\begin{array}{l}0.42-0.63 \\
(0.49 \pm 0.07)\end{array}$ & 0.51 & $\begin{array}{l}0.38-0.41 \\
(0.40 \pm 0.01)\end{array}$ & 0.42 \\
\hline $\begin{array}{l}\text { Eye-to-snout distance/ } \\
\text { Eye diameter }\end{array}$ & $\begin{array}{l}0.62-0.92 \\
(0.70 \pm 0.09)\end{array}$ & $\begin{array}{l}0.57-0.77 \\
(0.65 \pm 0.08)\end{array}$ & $\begin{array}{l}0.55-0.77 \\
(0.64 \pm 0.07)\end{array}$ & 0.54 & $\begin{array}{l}0.70-0.88 \\
(0.81 \pm 0.09)\end{array}$ & 0.89 \\
\hline $\begin{array}{l}\text { Disc of Finger III/Eye } \\
\text { diameter } 1,2\end{array}$ & $\begin{array}{l}0.25-0.40 \\
(0.32 \pm 0.04)\end{array}$ & $\begin{array}{l}0.32-0.37 \\
(0.34 \pm 0.02)\end{array}$ & $\begin{array}{l}0.22-0.44 \\
(0.32 \pm 0.07)\end{array}$ & 0.37 & $\begin{array}{l}0.41-0.50 \\
(0.44 \pm 0.05)\end{array}$ & 0.42 \\
\hline $\begin{array}{l}\text { Eye-to-snout/Interorbital } \\
\text { distance }\end{array}$ & $\begin{array}{l}0.73-0.92 \\
(0.84 \pm 0.06)\end{array}$ & $\begin{array}{l}0.79-0.96 \\
(0.86 \pm 0.07)\end{array}$ & $\begin{array}{l}0.71-1.27 \\
(0.97 \pm 0.25)\end{array}$ & 0.7 & $\begin{array}{l}0.84-1.00 \\
(0.90 \pm 0.08)\end{array}$ & 1.09 \\
\hline Femur length/SVL ${ }^{1}$ & $\begin{array}{l}0.46-0.54 \\
(0.51 \pm 0.24)\end{array}$ & $\begin{array}{l}0.47-0.54 \\
(0.51 \pm 0.03)\end{array}$ & $\begin{array}{l}0.53-0.61 \\
(0.56 \pm 0.02)\end{array}$ & 0.54 & $\begin{array}{l}0.55-0.58 \\
(0.56 \pm 0.01)\end{array}$ & 0.56 \\
\hline Tibia length/SVL & $\begin{array}{l}0.47-0.57 \\
(0.52 \pm 0.02)\end{array}$ & $\begin{array}{l}0.49-0.55 \\
(0.52 \pm 0.02)\end{array}$ & $\begin{array}{l}0.50-0.57 \\
(0.53 \pm 0.02)\end{array}$ & 0.52 & $\begin{array}{l}0.52-0.56 \\
(0.54 \pm 0.02)\end{array}$ & 0.56 \\
\hline
\end{tabular}

1 unequal variance $t$-test significant $(P<0.05)$ between males of $H$. fragile and $H$. orocostale
2 unequal variance $t$-test significant $(P<0.05)$ between males of $H$. orientale and $H$. orocostale

Fig. 3). However, differences between the calls of the individuals from Oriental Sector and Tobago were slight, and the values of most of the studied parameters overlapped. The advertisement calls from Cordillera del Interior were shorter $(0.17-0.20 \mathrm{~s}, 0.18 \pm$ 0.01 ) and had a lower dominant frequency (3382.63-3467.78 Hz, $3434.67 \pm 41.38)$. The calls also had a well-defined structure with maximum amplitude at the beginning of the call. Although more variable, the calls from Tobago and the Oriental Sector, were longer (Tobago: $0.21-0.30 \mathrm{~s}, 0.23 \pm 0.02$; Oriental Sector: $0.19-0.38$ s, $0.24 \pm 0.06$ ) and had a higher dominant frequency that never went under $4000 \mathrm{~Hz}$ (Tobago: 5341.12-5468.85 Hz, $5390.28 \pm 45.51$; Oriental Sector: 4574.75$5055.36 \mathrm{~Hz}, 4819.28 \pm 162.32$ ). Interestingly, the call structure of these was somewhat variable in amplitude and modulation, with some calls being slightly pulsed (Fig. 3B-D).

\section{Genetics}

Although no sample from Tobago could be analyzed, the three populations from the Cordillera de la Costa did not form a monophyletic group, and Hyalinobatrachium fragile was nested among samples from the Cordillera de la Costa (Fig. 4). The samples from the Cordillera del Interior were more closely related to $H$. fragile than to sequences from the Oriental Sector (where the type locality of $H$. orientale is situated), and the sequence from the Cordillera del Litoral is sister to the remaining sequences. The genetic distances (Table 4) suggest that each of the three different regions from the Cordillera de la Costa actually represents a different species, with zero intrapopulation distances and interpopulation distances around 6\%.

Based on these results, we consider Hyalinobatrachium orocostale from the Cordillera del Interior to be a valid species and resurrect it from synonymy with $H$. orientale.

\section{Species Account \\ Hyalinobatrachium orocostale new combination}

(Fig. 5)

Centrolenella orocostalis.-Rivero, 1968: 305.

Centrolenella orientalis.-Cannatella and Lamar, 1986:311.

Hyalinobatrachium orientalis.-Ruiz-Carranza and Lynch, 1991:24.

Hyalinobatrachium orientale.-Myers and Donnelly, 1997:16. 


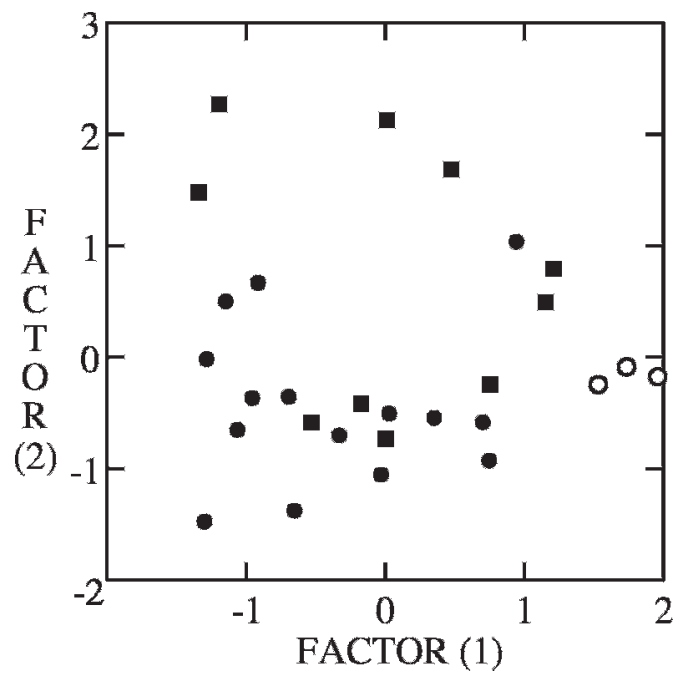

FIG. 2. Principal component analysis of body proportions in males of Hyalinobatrachium fragile (filled circles), $H$. orientale (squares), and H. orocostale (open circles). The first two factors explained $63.7 \%$ of the variance.

Holotype.-MCZ 47501, adult male, Cerro Platillón (Hacienda Picachitos), Cordillera del Interior, 1200 m, Guárico, Venezuela, collected by J. A. Rivero and A. E. Esteves on 26 October 1967.

Paratopotypes.-MHNLS 15108-9; USNM 166843; UPRM 002302, 002304-5, same data as holotype.

Paratype.-PRM 002308, adult male, Estación Biológica Rancho Grande, Cordillera del Litoral, Aragua, Venezuela, collected by J. A. Rivero and A. E. Esteves on 19 October 1967. This specimen most likely belongs to an undescribed species (see Remarks).

Referred specimens.-MHNLS 4738, adult female, same data as holotype; MHNLS 17297, adult male, same locality as holotype, collected by S. Castroviejo-Fisher, M. Natera, J. RuízMartín and D. González on 19 August 2004.

Diagnosis.-This species is placed in the genus Hyalinobatrachium because it has a bulb-shaped liver and males lack a humeral spine (Ruiz-Carranza and Lynch, 1991; Duellman and Señaris, 2003). The following combination of characters distinguishes $\mathrm{H}$. orocostale from other species of the genus: (1) dentigerous process on vomer and vomerine teeth absent; (2) snout truncate in dorsal and lateral view; (3) tympanum covered by skin (not visible through skin); (4) dorsal skin finely
TABLE 2.-Factor loadings of the principal component analysis of male body proportions of Hyalinobatrachium fragile, $H$. orientale and $H$. orocostale.

\begin{tabular}{lrr}
\hline & Factor 1 & Factor 2 \\
\hline Head width/Head length & -0.831 & 0.141 \\
Head length/SVL & 0.873 & 0.290 \\
Head width/SVL & 0.349 & 0.661 \\
Eye diameter/Head length & -0.623 & 0.760 \\
Eye-to-snout distance/Eye diameter & 0.619 & -0.329 \\
Disc of Finger III/Eye diameter & 0.352 & -0.555 \\
Eye-to-snout/Interorbital distance & -0.082 & 0.766 \\
Femur length/SVL & 0.590 & 0.622 \\
Tibia length/SVL & 0.441 & 0.457 \\
\hline
\end{tabular}

shagreened; (5) ventral skin granular, post cloacal warts and folds enameled; (6) parietal peritoneum and pericardiaum transparent, hepatic and visceral peritonea white; (7) bulb-shaped liver; (8) humeral spine absent; (9) hand webbing III $2^{-}-2 \mathrm{IV}$, absent between Fingers I and II and basal between Fingers II and III ; (10) foot webbing I $2^{-}$ $2^{-}$II $1-2^{1 / 2}$ III $1^{-}-3$ IV $3-1^{-} \mathrm{V}$; (11) ulnar and tarsal folds weakly enameled; (12) nuptial excrescence formed by group of glands on Finger I (Type V, these glands extend to the lateral fringes and membranes of the other fingers), glands slightly visible in the webbing between toes; (13) when adpressed, Finger I longer than II; (14) eye diameter larger than width of disc on Finger III; (15) in life, dorsum lime green with small yellow spots and minute melanophores, bones white; (16) in preservative, dorsum cream with minute dark melanophores; (17) in life, iris golden with black flecks; in preservative, iris cream with black flecks; (18) minute melanophores not extending throughout fingers and toes except base of Finger IV and Toe V; in life, tips of fingers and toes yellowish; (19) males call on underside of leaves; single and tonal note advertisement call with a duration of $0.173-0.195 \mathrm{~s}$, dominant frequency of 3382.63-3467.78 Hz; (20) fighting behavior unknown; (21) clutches located on underside of leaves consisting on 26-45 eggs; males occasionally guarding egg masses during night; (22) tadpole unknown; (23) SVL in males 19.7-20.5 mm $($ mean $=20.1 \pm 0.391 ; n$ $=3$ ); in one female $20.3 \mathrm{~mm}$.

We assign Hyalinobatrachium orocostale to the H. fleischmanni Group (Ruiz-Carranza and Lynch, 1991; 1998) because the species 


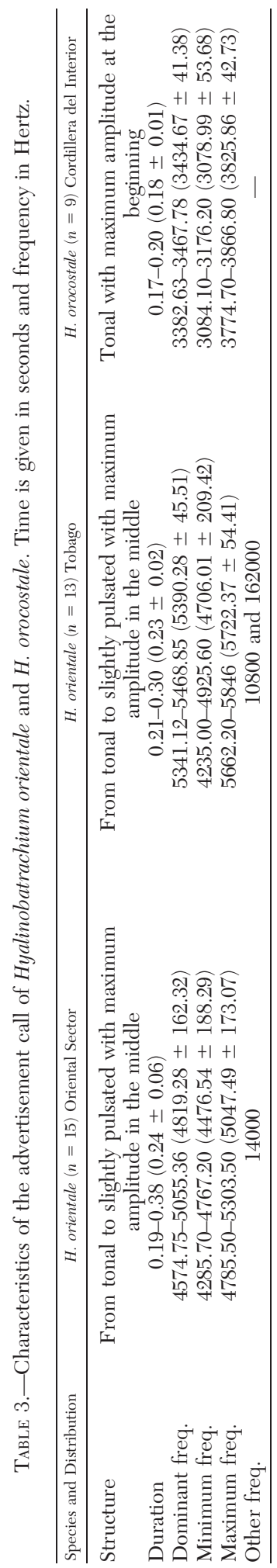

lacks vomerine teeth, deposits eggs underneath leaves and has white bones in life, transparent parietal and pericardial peritonea, and white visceral and hepatic peritonea. Centrolenids from the Cordillera de la Costa are isolated from those in other areas (Andes, Central America and the Guiana Shield) by unsuitable habitats and all the species in this area are endemics (Señaris and Ayarzagüena, 2005). Hence, the most similar species of the fleischmanni Group that inhabit the same area are $H$. fragile and $H$. orientale. Hyalinobatrachium fragile has a rounded snout in dorsal view (truncate in $H$. orocostale), most specimens $(72 \%)$ have $3-11$ big melanophores on the dorsum (only minute melanophores), and there were differences (unequal variance $t$ test) in males' head length/SVL $\left(t_{16,3}=5.281\right.$, $P=0.005)$, eye diameter/head length $\left(t_{16,3}=\right.$ $-3.743, P=0.005)$, disc of Finger III/eye diameter $\left(t_{16,3}=3.734, P=0.04\right)$, and femur length / SVL $\left(t_{16,3}=4.877, P=0.007\right)$ (Table 1); Hyalinobatrachium orientale from the Oriental Sector lacks glands on the lateral fringes of fingers and the membranes between them (present in $H$. orocostale) and some specimens-about 50\%-have big melanophores (absent); additionally, males of Hyalinobatrachium orientale had larger eye diameter/head length $\left(t_{10,3}=-3.973, P=0.002\right)$, smaller head length/SVL $\left(t_{10,3}=3.145, P=\right.$ 0.023), and disc of Finger III / eye diameter $\left(t_{10,3}=3.040, P=0.020\right)$ (Table 1$)$.

The advertisement calls of Hyalinobatrachium orientale, from both Tobago and the Oriental Sector, are clearly different from the one of $H$. orocostale in their dominant frequency, which is never under $4500 \mathrm{~Hz}$ $(<3500 \mathrm{~Hz}$ in $H$. orocostale), and have a mean duration of $0.239 \mathrm{~s} \pm 0.055$ in the Oriental Sector $(n=15)$ and $0.230 \mathrm{~s} \pm 0.002$ in Tobago $(n=13)$ (in H. orocostale mean $=$ $0.183 \mathrm{~s} \pm 0.007 ; n=9$ ). The advertisement call of $H$. fragile remains undescribed.

Color in life.-Dorsal surfaces lime green with small yellow spots, green areas dusted with minute melanophores not extending throughout fingers and toes except base of Finger IV and Toe V, tip of fingers and toes yellowish; iris golden with sparse dark flecks; skin of flanks and ventral surfaces translucent; enameled ulnar and tarsal folds as well as post 
A

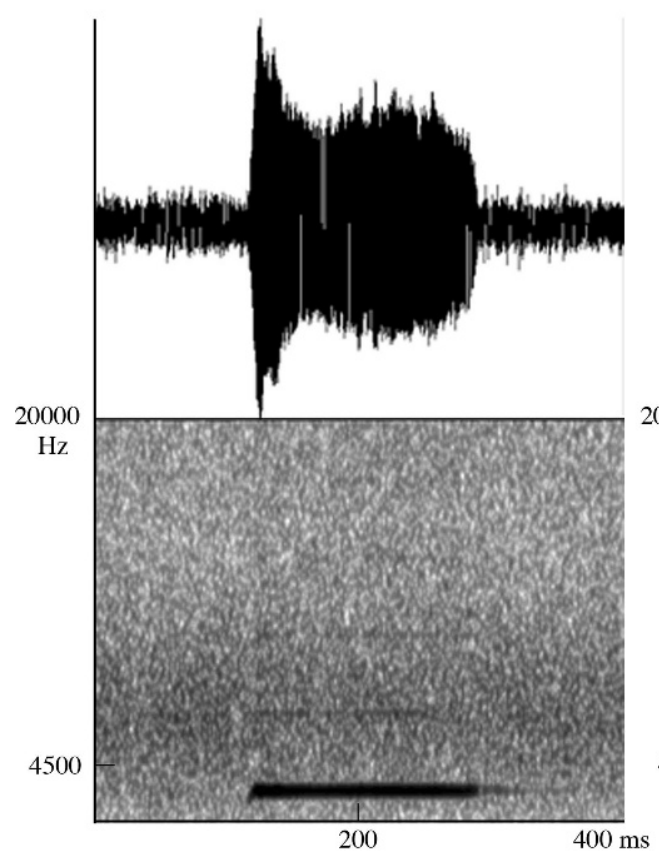

C

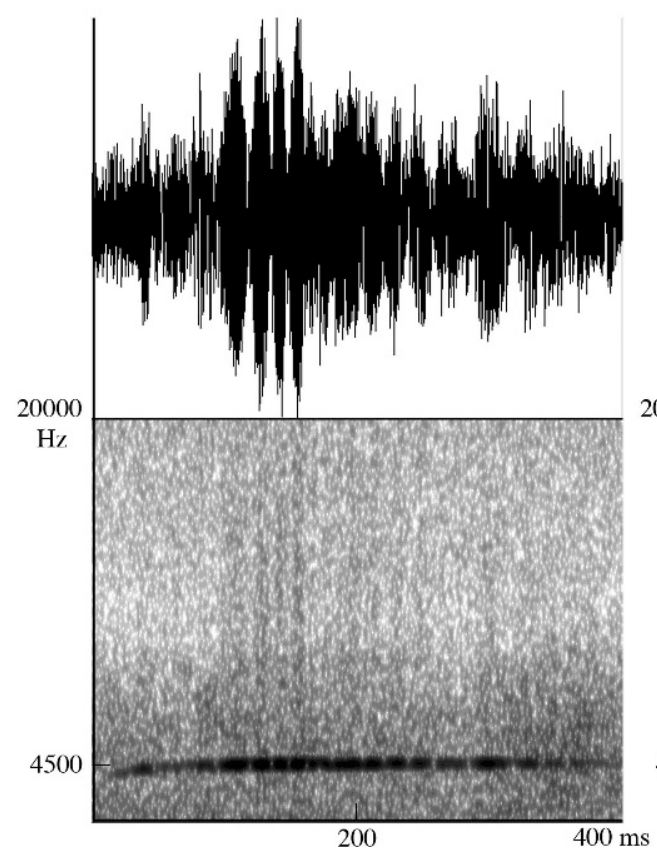

B

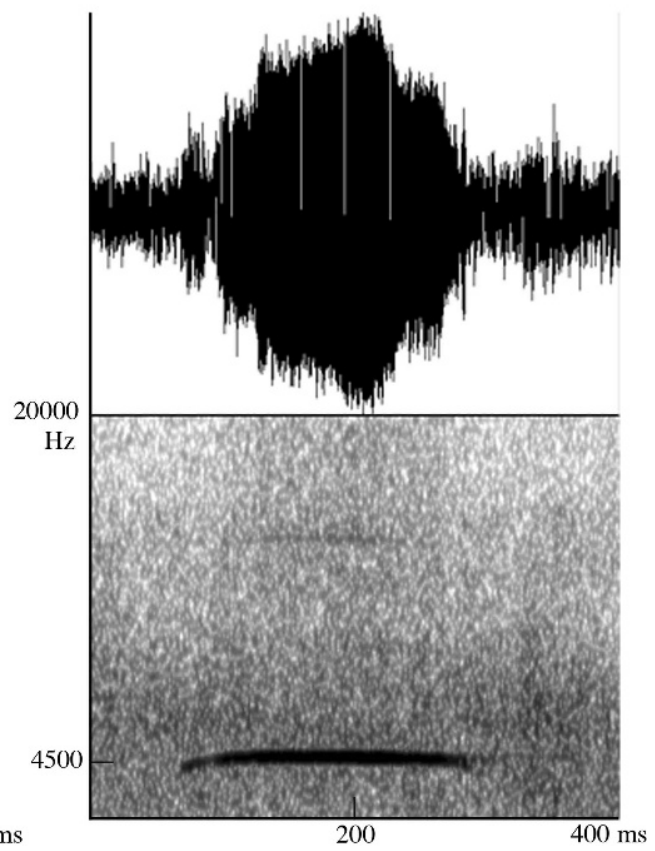

D

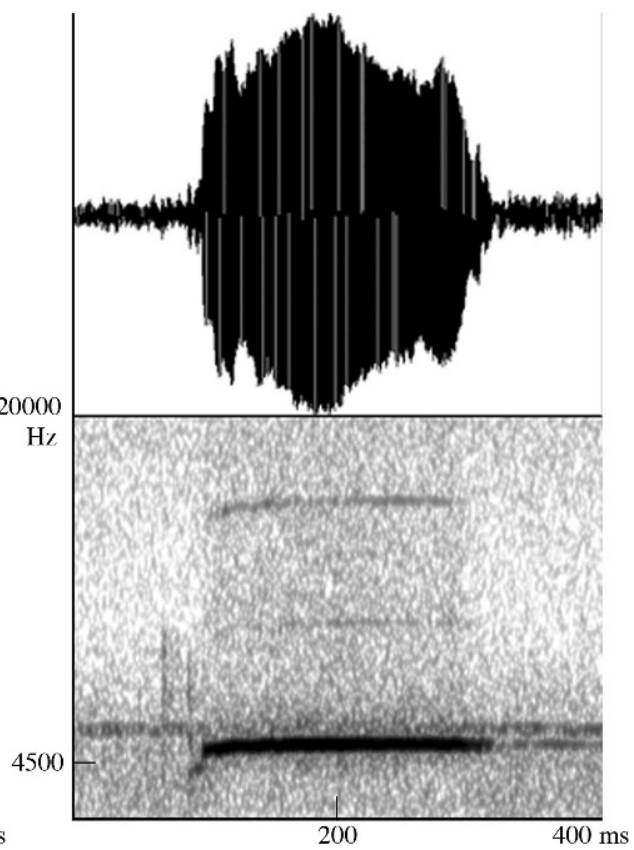

FIG. 3. Audiospectograms (upper figure) and oscillograms of advertisement calls of (A) Hyalinobatrachium orocostale, MHNLS 17247; (B) H. orientale, MHNLS 17297; (C) H. orientale, MHNLS 17117; and (D) H. orientale from Tobago, without voucher. 
cloacal warts and folds; parietal peritoneum and pericardium transparent, hepatic and visceral peritonea white; gall bladder is greenish; peritonea covering kidneys, gonads and urinary bladder transparent.

Color in preservative.-Dorsal surfaces cream, dusted with purple brownish melanophores; small cream spots free of melanophores; ventral surfaces whitish cream; peritonea as described above, although gall bladder cream.

Distribution and ecology.-This species is known from the type locality: Hacienda Picachito, Cerro Platillón $\left(09^{\circ} 51^{\prime} 23^{\prime \prime} \mathrm{N}\right.$, $67^{\circ} 30^{\prime} 09.1^{\prime \prime} \mathrm{W} ; 1200-1500 \mathrm{~m}$ ), Cordillera del Interior, Guárico, Venezuela. We suspect that it occurs in neighboring streams of the Cordillera del Interior. In 1994, C. Molina collected two specimens (MCNC 7806-7) from Hacienda La Canopia, between Villa de Cura and San Juan de los Morros, Aragua. This locality is approximately $20 \mathrm{Km}$ away from the type locality and we assume that the specimens are $H$. orocostale. However, the Cordillera del Interior is isolated from the Cordillera del Litoral by semi-arid valleys such as the Campos de Carabobo and the valleys of Aragua and Tuy; hence, we suspect that its distribution is restricted to this mountain chain.

We found Hyalinobatrachium orocostale along a medium size stream surrounded by pristine vegetation. A single specimen (MHNLS 17297) was collected on 19 August 2004, calling on the underside of a leaf at night $(21: 20 \mathrm{~h})$. We did not find any egg mass close to it. Although we were unable to catch more specimens (they were higher than $10 \mathrm{~m}$ in the canopy), the density of calling males was high, approximately 5-10 males along $25 \mathrm{~m}$ of stream. Additionally, at 21:30 h we found eight egg clutches, with 26-45 eggs each, on the underside of leaves of the same plant (approximate distance between egg masses $2-30 \mathrm{~cm}$ ), about $3 \mathrm{~m}$ above the running water and $30 \mathrm{~m}$ away from the collected specimen. The clutches were in different states of development. Those in early stages were in a single layer; however, those that were in advanced stages formed a multilayer due to growth of embryos (see Ruiz-Carranza and Lynch, 1998; Cisneros-

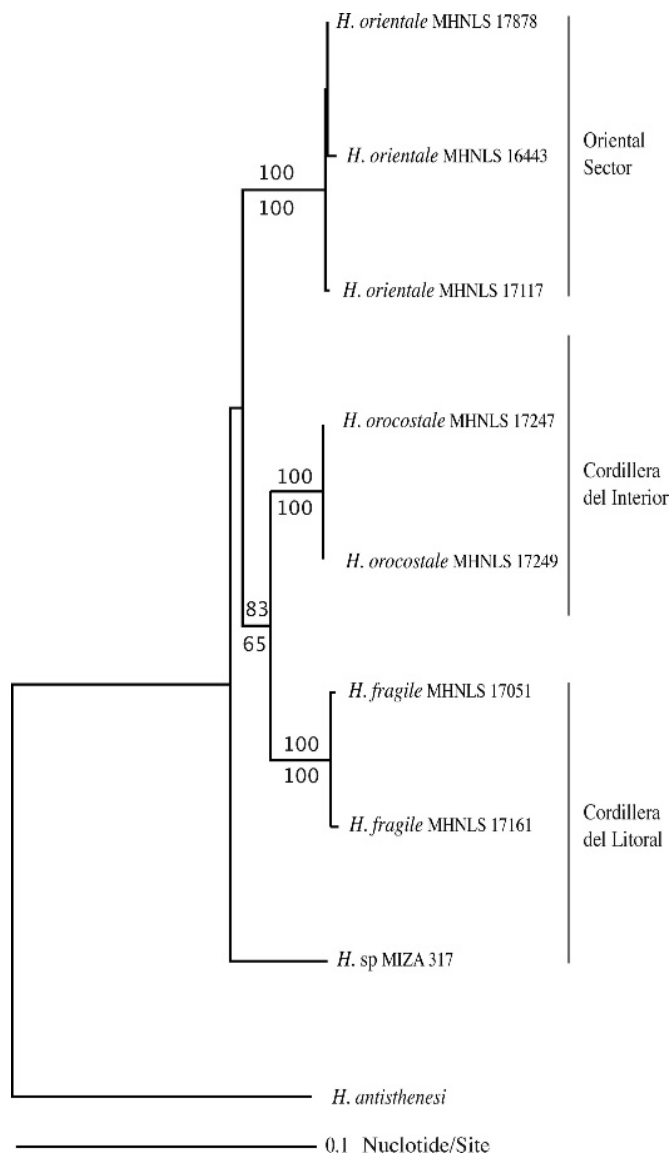

Fig. 4. Neighbor joining (NJ) tree based on about $850 \mathrm{bp}$ of the mitochondrial $16 \mathrm{~S}$ gene. Support is indicated by the node when boostrap values are $>80 \%$ in the NJ tree or $>65 \%$ in the maximum parsimony tree. Clades are labeled according to their distribution in the Venezuelan Cordillera de la Costa.

Heredia and McDiarmid, 2007; Altig and McDiarmid, 2007). We visited the clutches the two following nights and we did not find any guarding parent. However, Rivero (1968) indicated that the holotype was calling over an egg clutch.

Remarks.-The paratype series designated by Rivero (1968) offers problems, the first being the location of the specimens. In the original description, Rivero (1968) cited all the paratype series (seven specimens) as housed at the UPRM. However, at least some of this material has been moved to different institutions and these changes have remained unnoticed in relevant references. The paratypes cited by Rivero (1968) as UPRM 002303 
TABLE 4.-Inter- and intraspecific uncorrected pairwise distances (\%) between Hyalinobatrachium fragile, $H$. orientale, $H$. sp., and $H$. orocostale. The values in the diagonal represent intrapopulation divergences.

\begin{tabular}{llllll}
\hline \multicolumn{1}{c}{ Species and Distribution } & 1 & 2 & 3 & 4 \\
\hline $\mathbf{1}$ & H. fragile $(n=2)$ Cordillera del & 0 & & & \\
& Litoral \\
$\mathbf{2}$ & H. orientale $(n=3)$ Oriental Sector & 6 & 0 & & \\
$\mathbf{3}$ & H. sp. $(n=1)$ Cordillera del Litoral & 7 & 6.5 & - & \\
$\mathbf{4}$ & H. orocostale $(n=2)$ Cordillera del & 4 & 6 & 6 & 0 \\
& Interior
\end{tabular}

and UPRM 002306 were donated to the MHNLS and are now labeled MHNLS 15108 and MHNLS 15109 respectively (these specimens also hold the field numbers MCZ Y 22312 and MCZ Y 22315). The paratype UPRM 002307 (field number MCZ Y 22316) was donated to the USNM, now with the number 166843. We do not know where the remaining paratypes (UPRM 002302, 002304, 002305, 002308) are located at present. Second, one of the specimens (UPRM 002308) originally designated as a paratype was collected at the Rancho Grande Biological Station, Aragua, which is situated in the Cordilera del Litoral. However, the populations from the Cordillera del Litoral represent a different undescribed species (J. ValeraLeal, personal communication). Unfortunately, we could not examine this specimen.
Finally, we found a female $H$. orocostale (MHNLS 4738, field number MCZ Y 22314) collected by J. A. Rivero together with the rest of the type series. Although Rivero (1968) did not include this specimen in the original description, he donated it to MHNLS specifying that it was a paratype. Because this female was donated just after collection, we concluded that Rivero did not have a museum number for the specimen at the particular time of manuscript preparation and decided not to include it in the type series for this reason.

\section{DisCussion}

Our data do not support recognition of a broadly distributed Hyalinobatrachium orientale as suggested by Señaris and Ayarzagüena (2005). We found clear differences in the morphology, advertisement calls and genetics of the populations studied. Hence, we formally resurrect $H$. orocostale and limit its distribution to the humid mountainous forests of the Cordillera del Interior in the Cordillera de la Costa, Venezuela. Our genetic data suggest that the populations of the Cordillera del Litoral represent a different evolutionary lineage ( $H$. sp.), whose taxonomic description will be published elsewhere (J. Valera-Leal, personal communication). We consider the

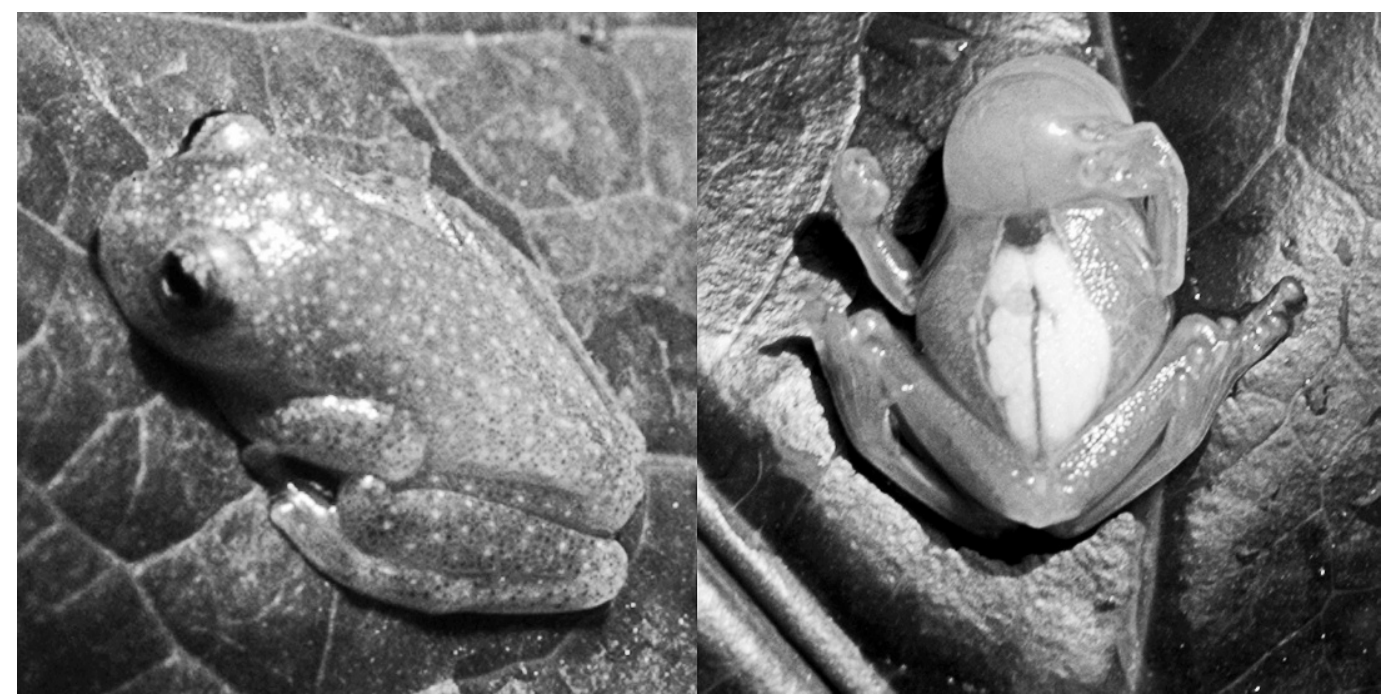

FIG. 5. Dorso-lateral and ventral view of Hyalinobatrachium orocostale, MHNLS 17247 (topotype), SVL $20.5 \mathrm{~mm}$. Photo by S. Castroviejo-Fisher. 
specimens from Tobago as part of $H$. orientale sensu stricto (Oriental Sector) based on advertisement call, morphology, and morphometric similarities (this work; Cannatella and Lamar, 1986). Nevertheless, its taxonomic status deserves further study.

We show how integrative taxonomy can establish species limits for species groups where morphological differences are subtle. Many cryptic species of anurans may exist (Bickford et al., 2007), and integrative approaches to taxonomy will aid researchers develop a more accurate estimation of alpha diversity in this group.

Acknowledgments.-For field assistance we thank M. Natera, J. Ruíz-Martín, D. González, J. M. Castroviejo and R. Antelo. For the loan of specimens, tissues and sharing unpublished data we thank I. De la Riva, R. Márquez and J. M. Padial (MNCN), J. M. Guayasamin (UK), J. Valera-Leal and J. Manzanilla (UCV), C. BarrioAmorós, M. Read, K. Tighe (USNM), and D. F. CisnerosHeredia. Collection and genetic permits from Venezuela were negotiated by the MHNLS. This study is included in the "Contrato Marco de Acceso a Recursos Genéticos N 0001, 11 Enero 2007" established by the Fundación La Salle de Ciencias Naturales and the Ministerio del Ambiente, Venezuela. This work was supported by grants from the Estación Biológica El Frío (SCF, CV and JA), Asociación Amigos de Doñana and its director J. Castroviejo Bolíbar (SCF, CV and JA), Stiftelsen Sven och Lilly Lawskis (SCF), Helge Ax:son Johnsons Stiftelse Foundation (SCF), Synthesis Project (European Union) ES-TAF-2827 and NL-TAF-4090 (SCF), Sederholms' stipend (SCF), the Royal Swedish Academy of Science (SCF), and the Swedish Research Council (CV and SCF). This article benefited from constructive comments from I. De la Riva and two anonymous reviewers.

\section{Literature Cited}

Altig, R., and R. W. McDiarmid. 2007. Morphological diversity and evolution of egg and clutch structure in amphibians. Herpetological Monographs 21:1-32.

AMPHIBIAWEB: INFORMATION ON AMPHIBIAN BIOLOGY AND Conservation. [web application]. 2006, Berkeley, California: AmphibiaWeb. Available at http://amphibiaweb. org/. Accessed: 12 March 2008.

Boersma, P., and D. Weenick. 2006. Praat: Doing Phonetics by Computer. Version 4.5.02. Free available software at http://www.fon.hum.uva.nl/praat/. Institute of Phonetic Sciences, University of Amsterdam, Amsterdam, The Netherlands.

Bickford, D., D. J. Lohman, S. S. Navjot, P. K. L. NG, R. Meier, K. Winker, K. K. Ingram, and I. Das. 2007. Cryptic species as a window on diversity and conservation. Trends in Ecology and Evolution 22:148-155.

Cannatella, D. C., and W. W. Lamar. 1986. Synonymy and distribution of Centrolenella orientalis with notes on its life history (Anura: Centrolenidae). Journal of Herpetology 29:307-317.
Cisneros-Heredia, D. F., and R. W. McDiarmid. 2007. Revision of the characters of Centrolenidae (Amphibia: Anura: Athesphatanura), with comments on its taxonomy and the description of new taxa of glassfrogs. Zootaxa 1572:1-82.

Darts, C. R., and D. C. Cannatella. 2004. Novel relationships among hyloid frogs inferred from $12 \mathrm{~S}$ and 16S mitochondrial DNA sequences. Molecular Phylogenetics and Evolution 31:462-475.

DE Queiroz, K. 1998. The general lineage concept of species, species criteria, and the process of speciation: A conceptual unification and terminological recommendations. Pp. 57-75. In D. J. Howard and S. H. Berlocher (Eds.), Endless Forms: Species and Speciation. Oxford University Press, Oxford, U.K.

Duellman, W. E., and J. C. Señaris. 2003. A new species of glass frog (Anura: Centrolenidae) from the Venezuelan Guayana. Herpetologica 59:247-252.

Frost, D. R. 2007. Amphibian Species of the World: an Online Reference. Version 5.0 (1 February, 2007). Electronic Database available at http://research.amnh. org/herpetology/amphibia/index.php. American Museum of Natural History, New York, New York, U.S.A.

Frost, D. R., T. Grant, J. Faivovich, R. H. Bain, A. Haas, C. F. B. Haddad, R. O. de Sa, A. Channing, M. Wilkinson, S. C. Donnellan, C. J. Raxworthy, J. A Campbell, B. L. Blotto, P. Moler, R. C. Drewes, R. A. Nussbaum, J. D. Lynch, D. M. Green, and W. C. Wheeler. 2006. The Amphibian Tree of Life. Bulletin of the American Museum of Natural History 297:1-370.

Flores, G. 1985. A new Centrolenella (Anura) from Ecuador, with comments on nuptial pads and prepollical spines in Centrolenella. Journal of Herpetology 13:313-320.

Gene Codes Corporation. 2000, Sequencher Version 4.1. Gene Codes Corporation, Ann Arbor, Michigan, U.S.A.

GoIn, C. 1964. Distribution and synonymy of Centrolenella fleischmanni in northern South America. Herpetologica 20:1-8.

Guayasamin, J. M., S. Castroviejo-Fisher, J. Ayarzagüena, L. Trueb, and C. Vilà. 2008. Phylogenetic relationships of glassfrogs (Centrolenidae) based on mitochondrial and nuclear genes. Molecular Phylogenetics and Evolution 48:574-595.

Guayasamin, J. M., M. R. Bustamante, D. AlmeidaReinoso, and C. W. Funk. 2006. Glass frogs (Centrolenidae) of Yanayacu Biological Station, Ecuador, with the description of a new species and comments on centrolenid systematics. Zoological Journal of the Linnean Society 147:489-513.

Guayasamin, J. M., and L. Trueb. 2007. A new species of Glassfrog (Anura: Centrolenidae) from the lowlands of northwestern Ecuador, with comments on centrolenid osteology. Zootaxa 1447:27-45.

Hardy, J. D., JR. 1982. Biogeography of Tobago, West Indies, with special reference to amphibians and reptiles: a review. Bulletin of the Maryland Herpetological Society 18:37-142.

Hardy, J. D., JR. 1984. A new species of Centrolenella orientalis (Anura: Centrolenidae) from Tobago, West Indies. Bulletin of the Maryland Herpetological Society 20:165-173. 
Hillis, D. M., C. Moritz, and B. K. Mable. 1996. Molecular Systematics, 2nd Edition. Sinauer Associates, Sunderland, Massachusets, U.S.A.

Huber, O. 1997. Ambientes Fisiográficos y vegetales de Venezuela. Pp. 279-298. In E. LaMarca (Ed.), Vertebrados Actuales y Fósiles de Venezuela Serie Catálogo Zoológico de Venezuela. Vol. I, Museo de Ciencias y Tecnología de Mérida, Venezuela.

Kok, P. J. R., and S. Castroviejo-Fisher. 2008. Glassfrogs (Anura: Centrolenidae) of Kaiteur National Park, Guyana, with notes on the distribution and taxonomy of some species of the family in the Guiana Shield. Zootaxa 1680:25-53.

Kubicki, B. 2007. Ranas de Vidrio de Costa Rica/Glass Frogs of Costa Rica. Editorial INBio. Santo Domingo de Heredia, Costa Rica.

Lynch, J. D., And W. E. Duellman. 1973. A review of the centrolenid frogs of Ecuador, with descriptions of new species. Occasional Papers, Museum of Natural History, University of Kansas 16:1-66.

Mazzoni, D., and R. Dannenberg. 1999. Audacity: a free, cross-platform digital audio editor. Version 1.2.6. Free Software Foundation, Boston, Massachusetts, U.S.A.

Murphy, J. C. 1997. Amphibians and Reptiles from Trinidad and Tobago. Krieger Publishing Company, Malabar, Florida, U.S.A.

Myers, C. W., And M. A. Donnelly. 1997. A tepui herpetofauna on a granitic mountain (Tamacuari) in the borderland between Venezuela and Brazil: report from the Phipps Tapirapeco' Expedition. American Museum Novitates 3213:1-71

ReaD, M. 2001. Frogs of Trinidad, Tobago and the Lesser Antilles. A Guide to their Calls. Morley Read Productions Readymoney Cove, Fowey, U.K.

Rivero, J. A. 1964. The distribution of Venezuelan frogs IV. The Coastal Range. Caribbean Journal of Science $4: 307-319$

Rivero, J. A. 1968. Los Centrolenidos de Venezuela (Amphibia, Salientia). Memoria de la Sociedad de Ciencias Naturales La Salle 28:301-334.

Ruiz-Carranza, P. M., and J. D. Lynch. 1991. Ranas Centrolenidae de Colombia I. Propuesta de una nueva clasificación genérica. Lozania 57:1-32.

Ruiz-Carranza, P. M., and J. D. Lynch. 1998. Ranas Centrolenidae de Colombia XI. Nuevas especies de ranas de cristal del genero Hyalinobatrachium. Revista de la Academia Colombiana de Ciencias Exactas, Físicas y Naturales 22:571-586.

Savage, J. M., and W. R. Heyer. 1967. Variation and distribution in the tree-frog genus Phyllomedusa. Beiträge zur Neotropischen Fauna 5:111-131.

Sambrook, J., E. F. Fritsch, and T. Maniatis. 1989. Molecular Cloning: A Laboratory Manual. Cold Spring Harbor Laboratory Press, New York, New York, U.S.A.

SeÑaris, J. C., and J. Ayarzagüena. 2005. Revisión taxonómica de la Familia Centrolenidae (Amphibia; Anura) de Venezuela. Publicaciones del Comité Español del Programa Hombre y Biosfera-Red IberoMaB de la UNESCO, Sevilla, España.

Simpson, G. G. 1961. Principles of animal taxonomy. Columbia University Press, New York, New York, U.S.A.

Swofford, D. L. 2002. PAUP*: Phylogenetic analysis using parsimony (*and other methods). Version 4.0b10. Sinauer Associates, Sunderland, Massachusetts, U.S.A.
Thompson, J. D., T. J. Gibson, F. Plewniak, F. Jeanmougin, and D. G. Higgins. 1997. The CLUSTAL_X windows interface: flexible strategies for multiple sequence alignment aided by quality analysis tools. Nucleic Acids Research 25:4876-4882.

Vences, M., M. Thomas, R. Bonett, and D. Vieites, D. 2005a. Deciphering amphibian diversity through DNA barcoding: chances and challenges. Philosophical Transactions of the Royal Society of London B 360:1859-1868.

Vences, M., M. Thomas, A. van der Meijden, Y. Chiari, AND D. R. Vieites. 2005b. Comparative performance of the 16S rRNA gene in DNA barcoding of amphibians. Frontiers in Zoology 2:5.

Will, K. W., B. D. Mishler, and Q. D. Wheeler. 2005. The perils of DNA barcoding and the need for integrative taxonomy. Systematyc Biology 54:844-851.

Wiley, E. O. 1978. The evolutionary species concept reconsidered. Systematic Zoology 27:17-26.

Wiens, J. J., J. W. Fetzner, Jr., C. L. Parkinson, and T. W. Reeder. 2005. Hylid Frog Phylogeny and Sampling Strategies for Speciose Clades. Systematic Biology $54: 719-748$.

\section{APPENDix I}

Specimens Examined and GenBank Accession Numbers

For specimens used in the phylogenetic analysis, GenBank numbers (in parentheses) follow museum numbers. Hyalinobatrachium antisthenesi: VENEZUELA, Aragua: MBUCV 4033 (holotype), MHNLS 17050 (EU447287); Cojedes: MHNLS 17162-3. Hyalinobatrachium crurifasciatum: VENEZUELA, Amazonas: MBUCV 6828 (paratype); Bolívar: MHNLS 171245, 17135, 17328. Hyalinobatrachium duranti: VENEZUELA, Mérida: UPRM 5811 (holotype), MHNLS $17164,17195,17197-0,17244,17246$ (topotypes), 17165-71. Hyalinobatrachium eccentricum: VENEZUELA, Amazonas: EBRG 3049 (holotype); Bolívar: MHNLS 17335. Hyalinobatrachium fleischamanni: COSTA RICA, Provincia San José: SMF 3760 (lectotype). NICARAGUA, Departamento Atlántico Norte: SMF 82882, 82878. Hyalinobatrachium fragile: VENEZUELA, Cojedes: UPRM 5938, 5560 (holotype and paratype), MHNLS 9660, 17161 (EU447286) (topotypes); Aragua: MHNLS 17051 (EU447285); Distrito Federal: MHNLS 4293-4, 4530-1, 4686; Yaracuy: MHNLS 9661, 9680-3, 9693-9702. Hyalinobatrachium guairarepanensis: VENEZUELA, Distrito Federal: MHNLS 1371 (holotype), 4930, USNM 128889, 128796-7, 128799 (paratypes). Hyalinobatrachium iaspidiense: VENEZUELA, Bolívar: EBD 28803-4 (holotype and paratype), MHNLS 17118, 17126 (topotype). Hyalinobatrachium ignioculus: GUYANA: UTA 51658 (paratype). Hyalinobatrachium mondolfii: VENEZUELA, Delta Amacuro: MHNLS 12710 (holotype), 17119-22 (topotypes). Hyalinobatrachium nouraguensis: FRENCH GUIANA: MNHNP 1999-8604-5 (holotype and paratype). Hyalinobatrachium orientale: VENEZUELA, Monagas: MHNLS 13353, 14750-2, 17117 (EU447283), MBUCV 3018 (three specimens); Sucre: MHNLS 13354, 16443 (EU447291), 17294, 17297, 17312, 17878 (EU447289), CET 2018, EBGRG 2577-8, 2584. Hyalinobatrachium 
orocostale: VENEZUELA, Guárico: MHNLS 15108-9 (paratypes), 4738, 17247 (EU447284), 17249 (EU447288) (topotypes). Hyalinobatrachium pallidum: VENEZUELA, Táchira: UPRM 4554 (holotype), MHNLS 13851, 17238 (topotypes). Hyalinobatrachium sp.: VENEZUELA, Aragua: MIZA 317 (EU447290). Hyalino- batrachium tatayoi: VENEZUELA, Zulia: MHNLS 17174 (holotype), MHNLS 17172-73, 17176-7, 1717984 (paratypes). Hyalinobatrachium taylori: Guyana: BMNH 1939.1.1.65 (holotype), 1939.1.1.64 (paratype); VENEZUELA, Bolívar: MHNLS 17141, 17279, 17281-2. 